\title{
Cervical Cancer pT1a2 TNM Finding v7
}

National Cancer Institute

\section{Source}

National Cancer Institute. Cervical Cancer pT 1a2 TNM Finding v7. NCI Thesaurus. Code C89529.

Invasive cervical cancer with measured stromal invasion more than $3.0 \mathrm{~mm}$ and not more than $5.0 \mathrm{~mm}$ with a horizontal spread $7.0 \mathrm{~mm}$ or less. (from AJCC 7th Ed.) 